\title{
Aleksandr Puškin: Russlands store dikter
}

\author{
Erik Egeberg \\ Oslo: Solum Bokvennen 2020 \\ 292 sidor. ISBN: 9788256022243
}

Recenserad av Julie Hansen [docent i slaviska språk vid Institutionen för moderna språk, Uppsala universitet]

Som många romantiker levde Aleksandr Pusjkin (1799-1837) ett intensivt liv. Trots sin förtida död i en duell, endast 37 år gammal, lämnade Pusjkin efter sig en bred och mästerlig produktion inom flera genrer - lyrik, dramatik, skönlitterär och historisk prosa, samt nyskapande hybridverk som versromanen Evgenij Onegin. Två hundra år senare fascineras läsare fortfarande av den ryske nationalskalden. Ryska filologer har kartlagt så gott som varenda dag i Pusjkins liv och de senaste decennierna har sett nya Pusjkinbiografier på engelska, franska och tyska. Som den första skandinaviska Pusjkinbiografin på mycket länge är Erik Egebergs bok Aleksandr Puškin: Russlands store dikter särskilt välkommen. Egeberg är professor emeritus i rysk litteratur vid Universitetet i Tromsø, litterär översättare och ledande specialist på rysk 1900-talslitteratur.

Att Pusjkin i ett internationellt perspektiv är mindre känd än andra nationalskalder som Goethe och Shakespeare kan förklaras av svårigheterna med att översätta hans lyrik, präglad som den är, som Egeberg skriver, av knapphet, pregnans och smidighet (s. 178). Det är inte heller en enkel uppgift att skriva en biografi över ett kulturhelgon: "den som uttaler seg om Puškin, [må] stadig være på vakt for ikke å mistolke opplysninger eller uforvarende støte noen. For Puškin er slett ingen enkel person [...] Det samme gjelder den tid og det samfunn han levde i» (s. 12). Dock lyckas Egeberg väl med att ur det omfattande källmaterialet förmedla en nyanserad bild av Pusjkin såväl som människa som litterärt geni. Porträttet får liv och färg av Egebergs kunskaper om poetens sociala och politiska kontext. Diktningen var för Pusjkin sprungen ur "et dypt indre behov» (s. 41), menar Egeberg, men den både formades av och svarade på hans samtid. Det är ingen tillfällighet att Sovremennik (Den samtida) blev titeln på Pusjkins egen tidskrift som grundades 1836.

Bokens 15 kapitel är uppdelade efter perioder och platser i Pusjkins liv och följer kronologiskt hans litterära utveckling i samspel med personliga och politiska 
omständigheter. Egeberg beskriver de litterära salonger där Pusjkin läste upp sina verk, förälskade sig i adelskvinnor och stiftade bekantskap med andra författare, som till exempel den polske romantikern Adam Mickiewicz. I sina verk skapade Pusjkin synteser av olika traditioner, språk, källmaterial och genrer samt omsatte personliga erfarenheter "til noe allmengyldig, typisk, til noe som alle mennesker har en mulighet til å kjenne igjen» (s. 147).

I en tid då allt fler efterfrågade samhällsförändringar kunde dikter vara farliga och det dröjde inte länge innan Pusjkin kom i konflikt med statsmakten. Alexander I förvisade Pusjkin under fyra år till södra Ryssland och senare till familjens gods Michajlovskoe, där poetens egen far fick i uppdrag att övervaka sonen och öppna hans brev. Delvis på grund av förvisningen var Pusjkin inte medlem i de hemliga sällskapen bakom dekabristupproret 1825 och poeten hoppades på mer frihet från den nykrönte Nikolaj I, men han blev aldrig fri från censur. Baron Alexander von Benckendorff, chef för den hemliga polisen under Nikolaj I, är en återkommande bifigur i Egebergs bok.

Romantiken var också en tid av litterära fejder, kränkt heder och dueller. Pusjkin hade fiender men också trogna vänner som hjälpte och beskyddade honom, bland dem författarna Nikolaj Karamzin och Vasilij Zjukovskij. Egeberg spekulerar att utan sådana vänner hade "[d]en ulykkelige skjebne som rev ham bort så tidlig [godt] kunne ha innhentet ham lenge før» (s. 71). Pusjkin gifte sig 1831 med den vackra Natalja Gontjarova. Äktenskapet var lyckligt men förde enligt Egeberg »dikteren inn $i$ et nett av intriger som skulle volde hans død» (s. 211). Mot slutet av sitt liv var Pusjkin alltmer pressad av penningbrist såväl som av tsarens förväntningar. Egeberg lägger fram ett intressant resonemang om Pusjkin som ett möjligt mobbningsoffer i hovmiljön, en främmande fågel som varit i politisk förvisning, en författare med en vass tunga som ville försörja sig på litteratur. Egeberg menar att Pusjkin kände sig så pass utsatt att han kan ha betraktat duellen med fransmannen Georges d'Anthès (som hade förälskat sig i Pusjkins fru) som ett sätt - oavsett utfall - att befria sig från en ohållbar situation.

Genomgående tillför Egeberg fascinerande kulturhistorisk kontext genom korta nedslag i ämnen som till exempel frimurarna i Ryssland. Han belyser Pusjkins tvåspråkiga uppväxt med franskan som familjens och skönlitteraturens språk å ena sidan och ryskan som tjänstefolkets och sagornas språk å den andra. På lycéet i Tsarskoe selo fick Pusjkin högsta betyg i både rysk och fransk litteratur samt fäktning. Han förbättrade senare sin engelska för att kunna läsa lord Byron, vars »östliga berättelser» influerade Pusjkins sydliga dikter, "Fången i Kaukasus» (1822) och "Springbrunnen i Bachtjisaraj» (1824).

Också av intresse är Egebergs redogörelse för den samtida och senare receptionen av Pusjkins verk. Han berättar om numera bortglömda författare som konkurrerade med Pusjkin och om Pusjkins inflytande på senare författare som Dostojevskij. Boken avslutas med ett urval av Pusjkins dikter i Egebergs egen vackra översättning. 
Ett helt kapitel ägnas åt versromanen Evgenij Onegin, som tog åtta år för Pusjkin att skriva (1823-31) och som Egeberg sammanfattar utmärkt på endast åtta sidor. Egeberg noterar att läsaren är en viktig person i versromanen: »det velvillige vennskapsforhold som dikteren etablerer mellom seg og leseren, betinger den uhøytidelige tone» (s. 168).

Man skulle kunna säga samma sak om denna Pusjkinbiografi, som ger en känsla av att Egeberg samtalar med läsaren och går hen till mötes genom att ibland dra paralleller till den nordiska kontexten (bland annat upptäcks en intressant likhet mellan statyerna i Pusjkins Bronsryttaren och Selma Lagerlöfs Nils Holgerssons underbara resa genom Sverige). Sammantaget är det en mångfacetterad levnadsteckning med lysande tolkningar som ger mersmak på Pusjkins verk. 